\title{
THE EFFECTIVENESS OF "PEER GROUP DISCUSSION" IN IMPROVING HEALTH CADRE'S KNOWLEDGE ABOUT DANGER SIGNS IN THE MATERNAL PERIODS
}

\author{
Ermiati $^{1}$, Anita Setyawati ${ }^{2}$, Etika Emaliyawati ${ }^{3}$ \\ ${ }^{1,2,3}$ Faculty of Nursing, Universitas Padjadjaran, Bandung, Indonesia \\ Correspondence: ermiati@unpad.ac.id
}

\begin{abstract}
Limited health literacy is one of the causes of late detection related to danger signs in pregnancy, postpartum and newborns. Health cadres are one of the main resources for early detection and dissemination of health information in the community. The purpose of this study was to determine the effectiveness of the peer group discussion method in increasing the knowledge of health cadres about danger signs in pregnancy, postpartum and new-borns (maternal periods). This research was Quasiexperimental study with a pre-test and post-test design. The stages of intervention in this study included training on danger signs with the lecture method followed by small group discussions (5-6 people) for 30 minutes, and practicing early warning signs detection. Questionnaires were given before and after training. The population in the study were all health cadres at Penanjung Health Center, while the sample was 32 health cadres from the health post (POSYANDU) Sari Asih. The Wilcoxon test was used to determine whether there was a difference in knowledge before and after training. The results showed the midpoint of the pregnancy danger signs before intervention 66.7 and after the intervention was 100. Middle value of postpartum danger signs knowledge before intervention 70 and after intervention 100. Midpoint knowledge of danger signs in newborns before intervention 75 and after intervention 100. The results of the bivariate analysis of the Wilcoxon Test before and after the intervention showed a p-value of 0,000 which means that there were significant differences before and after the intervention related to the danger signs in the maternal periods. Training on health cadres with this method increases cadres' knowledge about danger signs in pregnancy, postpartum and newborns.
\end{abstract}

Keywords: Danger sign, health care, newborns, postpartum, pregnancy, training

\section{INTRODUCTION}

According to the results of the Indonesian Health Demographic Survey, the Maternal Mortality Rates (MMR) in Indonesia recorded around 305 / 100,000 live births in 2015 (RI Ministry of Health, 2016). Riftana (2013) stated the causes of high maternal mortality rates are closely related to high-risk pregnancies. It is proven that the most common cause of maternal mortality in Indonesia from 2010-2013 is bleeding and hypertension. Indirect causes of maternal mortality were also sufficient at $40.8 \%$ in 2013. High-risk pregnancies are one of the conditions that increase the risk of complications of pregnancy, childbirth and postpartum (Society for Maternal-Fetal Medicine, 2010). 
In dealing with problems of maternal and infant mortality, one of the way is by approaching the mother, family, and community by health workers, and focusing on empowering the mother, family, and active role of the community (Prasetyawati, 2012). The active role of the community can be done by increasing knowledge. To increase public knowledge about the importance of health during pregnancy, early detection of complications of pregnancy, and actions in overcoming of complications are carried out by disseminating information and health education.

The involvement of cadres in improving public health must be supported by the knowledge and abilities of cadres in conducting health education including the ability to detect danger signs of pregnancy, postpartum and newborns. Limited knowledge thought to be one of the causes of late detection of danger signs in pregnancy, postpartum and maternal periods. The purpose of this study was to determine the effectiveness of the peer group discussion method in increasing health cadres' knowledge of danger signs in maternal periods.

\section{METHODS}

This research was a Quasi-experimental study with a pre-test and post-test design. Respondents in the study were given a pre-test for 20 minutes, then lectures on danger signs on the maternal periods, followed by small group discussions (5-6 people in groups) for 30 minutes, the last 30 minutes was early detection of danger signs simulation to pregnant women. After the intervention, respondents were given a posttest for 20 minutes. The population in this study was all health cadres in the PHC of Penanjung. The sample of this study was 32 health cadres from the POSYANDU of Sari Asih. Data were analyzed using univariate and bivariate. The Wilcoxon test is used to 
determine whether there is differences in health cadres' knowledge before and after the interventions.

\section{RESULTS}

Characteristics of Respondents

Table 1. Characteristics of respondents $(n=32)$

\begin{tabular}{lccccc}
\hline \multicolumn{1}{c}{ Characteristics } & Median & Mean & SD & Min & Max \\
\hline Age & 36,5 & 38,4 & 10,79 & 24 & 60 \\
The length being a cadre & 6,8 & 2,5 & 8,1 & 1 & 30 \\
\hline
\end{tabular}

Table 1 revealed that the age of respondents ranged between 24-60 years, with the average was 38.4 years.

Table 2. The history of health cadre's formal education

\begin{tabular}{lcc}
\hline Education & n & \% \\
\hline Primary (Elementary and Junior High & 18 & $56,25 \%$ \\
School) & 12 & $37,5 \%$ \\
Secondary (Senior high School) & 2 & $6,25 \%$ \\
University (D1-S3) & & \\
\hline
\end{tabular}

Table 2 showed that the majority of respondents attended primary education in elementary and junior high school (56.25\%).

An overview of the mid-point of cadres' knowledge before and after health education

Table 3. Differences in health cadres' knowledge about danger signs in pregnancy, postpartum and newborns before and after health education

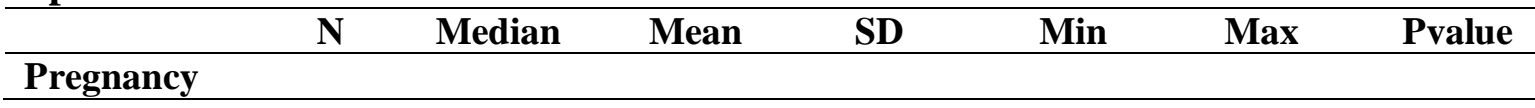




\begin{tabular}{lccccccc}
\hline Before & 32 & 66,7 & 65,8 & 7,71 & 46,7 & 93,3 & 0,000 \\
$\quad$ After & 32 & 100 & 98,1 & 4,55 & 73,3 & 100 & \\
Postpartum & & & & & & & \\
Before & 32 & 70 & 69,4 & 12,68 & 50 & 90 & 0,000 \\
$\quad$ After & 32 & 100 & 99,4 & 2,45 & 90 & 100 & \\
Newborn & & & & & & & \\
Before & 32 & 75 & 71,6 & 13,9 & 50 & 90 & 0,000 \\
After & 32 & 100 & 98,7 & 3,36 & 90 & 100 & \\
\hline
\end{tabular}

Table 3 revealed that the mid-point of danger signs knowledge before the intervention was 66.7 and after the median intervention was 100. The results of the bivariate analysis of the t-test before and after the intervention obtained $p$-value 0,000 which means there was a significant difference in the median value of knowledge about the danger signs in pregnancy before and after the intervention.

The median value of danger signs knowledge in the postpartum period before the intervention was 70 and after the intervention was 100 . The results of the bivariate analysis of the t-test before and after the intervention were obtained p-value 0,000 which means there was a significant difference in the median value of knowledge about postpartum danger signs before and after the intervention.

The median value of danger signs knowledge of newborns before the intervention was 75 and after the intervention was 100 . The results of the bivariate analysis of the $t-$ test before and after the intervention were obtained p-value 0,000 which means there was a significant difference in the median value of knowledge about the newborn before and after the intervention.

\section{DISCUSSION}

This study found that the respondents' age was in the adult age group category. The older, the more mature of individual thinking and working. In terms of public trust, a mature person is trusted by others. The age of the respondent has a big influence on a 
person's performance, older age would affect a person's experience, and personal physical and mental conditions are reflected in their daily life (Purnama \& Fenita. 2014).

The length of time respondents become a cadre was ranged from 1 to 30 years, with an average of 2.5 years. The longer you become a cadre, the more experience you have so that health knowledge would improve. The length of the period to become a cadre also shows the level of loyalty of cadres to the activities they engage in. This shows that they are very enjoyed as cadres. The longer a person in pursuing a field, the more experience, and skills in carrying out work (Wahyudi, 2010). These conditions would increase their self-confidence and determine the right attitude when facing a job or problems so that the quality of performance would be better (Sutaip, 2012).

Low education greatly influences someone in capturing the information they received. The level of formal education also influences a person's lifestyle especially in the motivation to do something. The higher the level of knowledge of a person, the easier in receiving information so that more knowledge will be possessed, and vice versa the lower the education the more difficult in receiving information. Education greatly determines one's performance. The higher the education of eating, the higher the desire to utilize knowledge and skills (Dewi \& Wiku, 2012).

The findings revealed that cadre's knowledge has increased after training, discussion and simulation. The increase in the mid-point value of the pretest to posttest was very good. The results showed that there were significant differences in the statistical test of cadre knowledge scores before and after the intervention with a value of $p=0,000$. This showed that the intervention in the form of cadre training with lecture, discussion and simulation methods, effectively increases the knowledge of 
health cadres about risk signs in pregnancy, postpartum and newborns. All cadres experienced a very good increase in knowledge, 26 cadres had scored perfectly in the sub-variable signs of high risk of pregnancy, 28 cadres had scored perfectly in subvariable risk signs in newborns and 30 cadres had received perfect scores in subvariable high-risk signs in the postpartum period, this is possible because of the variety of training methods used so that the material provided can be well understood by cadres. Harsono, Soesanto, and Samsudin. (2009) stated that the lecture method should be accompanied by interesting learning media so that it is not boring. In this training, the methods provided varies methods and stimulated participants to be active. A lecture on danger signs was done with powerpoint media which ended with a question and answer session. After the lecture continued with small group discussions totaling 5-6 cadres in each group accompanied by a tutor (the tutor was part of the research team) who helped the group to understand the training material. The discussion in the group was given 30 minutes after the discussion continued with a pregnancy detection simulation. There was a pregnant woman as the model in the simulation section, and cadres were asked to do detection using a checklist for early detection of risk condition in pregnancy, postpartum and newborns.

The application of several methods in this training increased the cadre's knowledge significantly that almost $80 \%$ of the participants obtained 100 scores. This shows that all the material presented in this training can be understood by almost all cadres. The research results of Tarigan (2015) state that the lecture, discussion, and module methods can increase knowledge. Training on health cadres using the lecture method, small group discussions, and simulations about danger signs in postpartum, pregnancy and newborns have increased the knowledge of health cadres in Pananjung 
village, Pangandaran District, Pangandaran Regency. Health cadres who are the main resources for disseminating information to the public are expected to share information about these danger signs to the public.

\section{CONCLUSION}

Training on health cadres using the lecture method, small group discussions, and simulations of danger signs in pregnancy, postpartum and newborn babies are effective in increasing the knowledge of Posyandu Sari Asih health cadres in Pananjung village, Pangandaran District, Pangandaran Regency.

\section{REFERENCES}

Dewi dan Wiku. 2012. Hubungan Karakteristik Perawat, Isi Pekerjaan dan Lingkungan Pekerjaan Terhadap kepuasan Kerja Perawat di Instansi Rawat Inap Gunung Jati Cirebon ., Jurnal Keperawatan UI.; 9 (1); 1-8.

Harsono, B., Soesanto., dan Samsudin. (2009). Perbedaan hasil belajar antara metode ceramah konvensional dengan ceramah berbantuan media animasi pada pembelajaran kompetensi perakitan dan pemasangan system rem. Jurnal Pendidikan Tehnik Mesin vol.9 no.2

Kemenkes RI. (2016). Profil Kesehatan Indonesia 2015. Jakarta: Kementerian Kesehatan RI.

Kementerian Kesehatan Republik Indonesia. (2011). Jaminan Persalinan, Upaya Terobosan Kementerian Kesehatan dalam Percepatan Pencapaian Target MDGs. 
Retrieved from http://www.kesehatanibu.depkes.go.id/archives/99

Kementrian Kesehatan RI. (2013). Profil Kesehatan Indonesia Tahun 2012. Jakarta.

Prasetyawati, A. E. (2012). Kesehatan Ibu dan Anak (KIA) dalam Millenium Development Goals (MDG'S). Yogyakarta: Nuha Medika.

Purnama dan Fenita. (2014). Beberapa faktor yang berhubungan dengan kinerja perawat dalam pengelolaan Sensus Harian Rawat Inap di RSUD Kota Semarang . Skripsi. Semarang : FKM UNDIP Pusdatin Depkes RI, 2007, Riset Kesehatan Dasar ( RISKESDAS ), Depkes RI, Jakarta Sugiyono PD, 2008. Metodologi Penelitian Pendekatan Praktis dan Aplikatif, Bandung : Alfabeta.

Riftana, F. D. C. (2013). Hubungan Tingkat Pengetahuan Tentang Kehamilan Risiko Tinggi Dengan Persiapan Persalinan Pada Ibu Hamil Usia Remaja Di Wilayah Kerja Puskesmas Bangsalsari Kabupaten Jember. Program Studi Ilmu Keperawatan Universitas Jember.

Society for Maternal-Fetal Medicine. (2010). High-Risk Pregnancy Care, Research, And Education For Over 35 Years, 1-34. Retrieved from papers2://publication/uuid/F83F6842-D7D2-4D08-8181-3F077753767E

Sutaip. (2012). Faktor-Faktor Yang Berhubungan Dengan Kinerja Pelaporan Data Pelayanan KIA oleh Bidan Praktek Swasta di Kota Semarang Tahun 2012. Jurnal kesehatan Masyarakat Universitas Diponegoro

Wahyudi, I. (2010). Hubungan Persepsi Perawat Tentang Profesi Keperawatan, Kemampuan dan Motivasi Kerja Terhadap Kinerja Perawat Pelaksana di RSUD dr. Slamet Garut. Tesis . Universitas Indonesia

Tarigan, APS. (2015). Efektivitas Metode Ceramah Dan Diskusi Kelompok Terhadap Pengetahuan Dan Sikap Tentang Kesehatan Reproduksi Pada Remaja Di Yayasan 
Pendidikan Harapan Mekar Medan. Jurnal ilmiah Pannmed. Vol . 10 no.2 .

United Nations. (2013). The Millennium Development Goals Report 2013. New York. 